\title{
Successful freeze storage and lyophilisation for preservation of Helicobacter pylori
}

\author{
A Spengler, A Gross, H Kaltwasser
}

\begin{abstract}
Long term storage techniques for the preservation of Helicobacter pylori were developed. The cells survived at $-75^{\circ} \mathrm{C}$ in the presence of glycerol and at $+4^{\circ} \mathrm{C}$ after freeze-drying. Both techniques are suitable for routine use.
\end{abstract}

Most bacteria survive freeze-drying without loss of viability even after 30 years. ${ }^{1}$ One important exception is Helicobacter pylori. This fastidious organism which is associated with human active chronic gastritis ${ }^{2}$ was reported to be extremely sensitive to freezing and freezedrying. ${ }^{3-7}$

\section{Methods}

Strains of $H$ pylori $\mathrm{Hp} 151$ obtained from the Institut für Medizinische Mikrobiologie, Freiburg (Germany) were cultivated in Brucella broth (Difco) containing $2 \%$ fetal calf serum (FCS; Serva) and $10 \mathrm{mg}$ vancomycin (Sigma) per litre on a rotary shaker at $37^{\circ} \mathrm{C}$ for three days in an anaerobic jar under a gas mixture consisting of $5 \%$ oxygen, $10 \%$ carbon dioxide, and $85 \%$ nitrogen.

For preservation at $-75^{\circ} \mathrm{C}$, cells of a $200 \mathrm{ml}$ culture were harvested by centrifugation ( 20 minutes, $4^{\circ} \mathrm{C}, 11000 \times \mathrm{g}$ ) and suspended in $6 \mathrm{ml}$ of a sterile solution of $10 \%$ skimmed milk powder (Glücksklee, Germany) containing $17 \cdot 4 \%$ glycerol. This suspension was stored at $-75^{\circ} \mathrm{C}$ in sterile cryophials (Greiner Labortechnik, Germany) in portions of $2 \mathrm{ml}$. After one, three, eight, and 11 months some of these cultures were thawed and incubated with $48 \mathrm{ml}$ Brucella broth, as described above.

Institut für

Mikrobiologie,

Universität des

Saarlandes, Im

Stadtwald, 6600

Saarbrücken,

Germany

A Spengler

A Gross

H Kaltwasser

Correspondence to:

Dr Kaltwasser

Accepted for publication

31 January 1992.

\section{Results}

All cultures yielded profuse growth. The identity of the micro-organism was confirmed by microscopy, characteristic oxidase activity (oxidase test according to the method of Steel ${ }^{8}$ ), catalase activity (adding a $10 \% \mathrm{H}_{2} \mathrm{O}_{2}$ solution to the cell sediment of $H$ pylori), and by urease activity using a modified urease test according to the method of Romano et al ${ }^{\rho}$ with a $10 \mathrm{mM}$ phosphate buffer (pH 6), $1 \mathrm{mM}$ urea, and $0.01 \%$ (w/v) Cresol red. Moreover, golden pigmented colonies, which are characteristic for $H$ pylori, developed on modified Belo Horizonte agar (BHM), according to Queiroz et al, ${ }^{10}$ with Brucella agar base and Campylobacter Selective Supplement (Merck). The agar plates were incubated in an anaerobic jar with the Anaerocult- $\mathrm{C}$ system (Merck) at $37^{\circ} \mathrm{C}$ for three days.

For lyophilisation, $0.5 \mathrm{ml}$ aliquots of $20 \%$ skimmed milk powder solution (Oxoid) were sterilised at $115^{\circ} \mathrm{C}$ for eight minutes and freeze-dried under vacuum for 24 hours. Portions of 50-100 $\mu$ l volume of a dense $H$ pylori suspension were added on to this carrier material, followed by freezing and drying under vacuum (GT2-Heraeus freeze-dryer) for 24 hours. The tubes were sealed and stored at $4^{\circ} \mathrm{C}$ for one, two, and 12 weeks. Cultures were successfully recultivated by incubation in Brucella broth; the identity and the purity of the organism was confirmed as described above. All cultures yielded profuse growth.

We thank Mrs A Sauer and Mrs R Schepp for their valuable technical assistance.

1 Rudge RH. Maintenance of bacteria by freeze-drying. In: Kirsop BE, Snell JS, eds. Maintenance of microorganisms. London: Academic Press, 1984:23-33.

2 Dooley CP, Cohen $\mathrm{H}$. The clinical significance of Campylobacter pylori. Ann Intern Med 1988;108:70-9.

3 Westblom TU, Barthel JS, Havey AD, Gonzalez FJ, Tarka EF, Everett ED. Long term freeze storage of Campylobacter pyloridis. ₹ Clin Pathol 1987;40:353-6.

4 Goodwin CS, McCullough CH, Boehm J. Successful lyophilization of Campylobacter pylori and spiral organisms from the stomachs of animals. Pathology 1989 21:227-9.

5 Owen RJ, On SLW, Costas M. The effect of cooling rate, freeze-drying suspending fluid and culture age on the preservation of Campylobacter pylori. ₹ Appl Bacteriol 1989;66:331-7.

6 Goodwin CS, Armstrong JA. Microbiological aspects of Helicobacter pylori (Campylobacter pylori). Eur $\mathcal{F}$ Clin Microbiol Infect Dis 1990;9:1-13.

7 Ansorg R, von Recklinghausen G, Pomarius R, Schmid EN. Evaluation of techniques for isolation, subcultivation, and Evaluation of techniques for isolation, subcultivation, and
preservation of Helicobacter pylori. $₹$ Clin Microbiol preservation of

8 Steel KJ. The oxidase reaction as a taxonomic tool. $f$ Gen Microbiol 1961;25:297-306.

9 Romano N, Tolone G, La Licata R, Ajello F. Urease activity of Ureaplasma urealyticum: Some properties of the enzyme. Microbiologica 1979;2:357-67.

10 Queiroz DMM, Mendes EN, Rocha GA. Indicator medium for isolation of Campylobacter pylori. F Clin Microbiol 1987;25:2378-9. 